\title{
Correction: Novel evidence that extracellular nucleotides and purinergic signaling induce innate immunity-mediated mobilization of hematopoietic stem/progenitor cells
}

\author{
Mateusz Adamiak ${ }^{1,2} \cdot K$ Kamila Bujko ${ }^{1} \cdot$ Monika Cymer $^{2} \cdot$ Monika Plonka $^{1} \cdot$ Talita Glaser $^{3} \cdot$ Magda Kucia $^{1,2}$. \\ Janina Ratajczak ${ }^{1} \cdot$ Henning Ulrich ${ }^{3} \cdot$ Ahmed Abdel-Latif $^{4} \cdot$ Mariusz Z. Ratajczak $^{1,2}$
}

(c) The Author(s) 2019. This article is published with open access

Correction to: Leukemia 32; 1920-1931 (2018);

https://doi.org/10.1038/s41375-018-0122-0;

published online: 30 March 2018

Following the publication of this article, the authors noted that the following should be included in the Acknowledgements section: "MA is the recipient of a START scholarship (0785) from FNP". The authors wish to apologise for any inconvenience caused.

\begin{abstract}
Open Access This article is licensed under a Creative Commons Attribution 4.0 International License, which permits use, sharing, adaptation, distribution and reproduction in any medium or format, as long as you give appropriate credit to the original author(s) and the source, provide a link to the Creative Commons license, and indicate if changes were made. The images or other third party material in this article are included in the article's Creative Commons license, unless indicated otherwise in a credit line to the material. If material is not included in the article's Creative Commons license and your intended use is not permitted by statutory regulation or exceeds the permitted use, you will need to obtain permission directly from the copyright holder. To view a copy of this license, visit http://creativecommons. org/licenses/by/4.0/.
\end{abstract}

Mariusz Z. Ratajczak

mzrata01@louisville.edu

1 Stem Cell Institute at James Graham Brown Cancer Center, University of Louisville, Louisville, KY, USA

2 Department of Regenerative Medicine and Center for Preclinical Studies and Technology, Warsaw Medical University, Warsaw, Poland

3 Department of Biochemistry, Institute of Chemistry, University of São Paulo, São Paulo, Brazil

4 Division of Cardiovascular Medicine, Gill Heart Institute, University of Kentucky, Lexington, KY, USA 